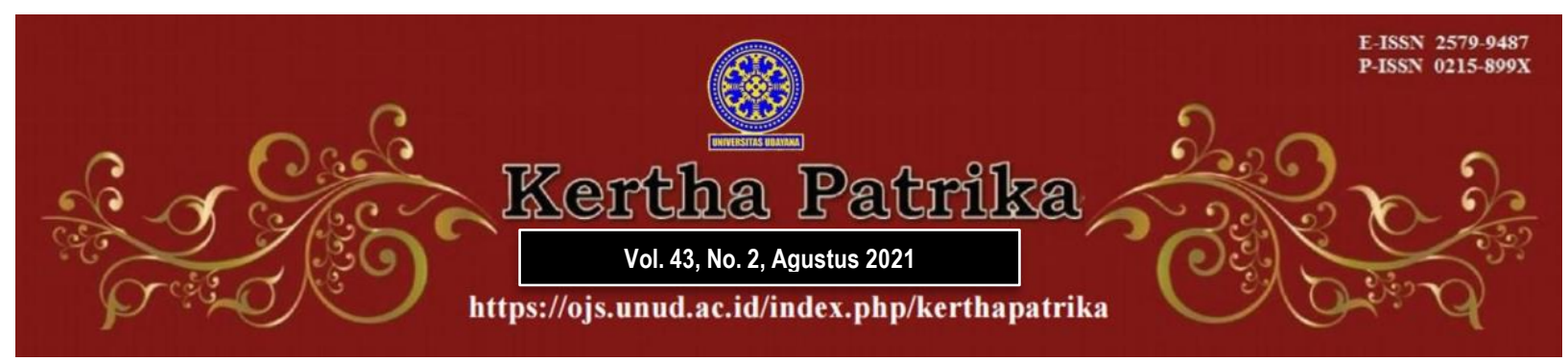

\title{
Keputusan Damang Pada Masyarakat Adat Dayak Dalam Menyelesaikan Kasus Perceraian di Kalimantan Tengah
}

\section{Made Kastama ${ }^{1}$, Ni Putu Paramita Dewi ${ }^{2}$}

${ }^{1}$ Fakultas Dharma Sastra IAHN-TP Palangka Raya, E-mail: kastamaimade@gmail.com ${ }^{2}$ Fakultas Dharma Sastra IAHN-TP Palangka Raya, E-mail: paramitaputudewi@gmail.com

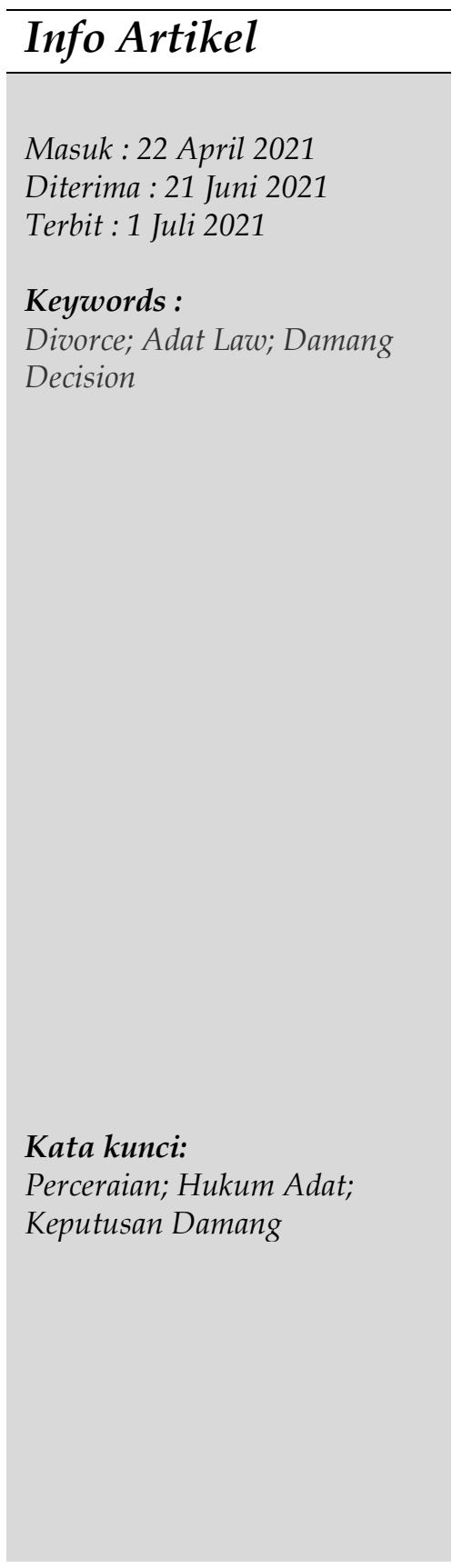

\begin{abstract}
Unresolved problems in the household are the trigger for a divorce. Indonesia still uses Customary Law, especially the Dayak Indigenous Peoples in Central Kalimantan Province, in resolving divorce cases. Dayak Indigenous Peoples through the Provincial Regulation of Central Kalimantan Number 16 of 2008 concerning Dayak Adat Institutions preserve the development and empowerment of the indigenous Dayak tribes. In its implementation, the Kedamangan Institution serves as a place to resolve problems, including divorce issues. Damang, who in this case has the authority to resolve divorce cases in the Dayak Customary Law community, must have the ability and good strategy in resolving and making efforts to prevent divorce cases. This research analyzes how the Kedamangan Institute, through the Damang Kepala Adat, resolves divorce cases in the indigenous Dayak community. This article is empirical juridical research and uses a qualitative approach. This study aims to provide information and insights to the public about the importance of resolving divorce cases under customary law because it can provide legal certainty through customary law. The result of this research is that the Damang Kepala Adat has the authority to settle divorce cases following the guidelines for the Dayak Adat court and issue a Customary Head Damang Decree, which can provide legal certainty for the parties.
\end{abstract}


Corresponding Author:

I Made Kastama, E-mail:

kastamaimade@gmail.com

DOI :

10.24843/KP.2021.v43.i02.p05 masyarakat Hukum Adat Dayak harus memiliki kemampuan dan strategi yang baik dalam menyelesaikan serta melakukan upaya pencegahan terhadap kasus perceraian. Penelitian ini menganalisis bagaimana Lembaga Kedamangan melalui Damang Kepala Adat menyelesaikan kasus perceraian pada masyarakat hukum adat Dayak. Artikel ini merupakan penelitian yuridis empiris dan menggunakan pendekatan kualtitatif. Penelitian ini bertujuan untuk memberikan informasi dan wawasan kepada masyarakat tentang sehingga dapat mengetahui tentang pentingnya menyelesaikan kasus perceraian secara Hukum Adat karena dapat memberikan kepastian hukum secara Hukum Adat. Adapun hasil dari penelitian ini adalah adanya kewenangan Damang Kepala Adat dalam melakukan penyelesian kasus perceraian sesuai dengan pedoman peradilan Adat Dayak dan mengeluarkan Surat Keputusan Damang Kepala Adat yang dapat memberikan kepastian hukum bagi para pihak.

\section{Pendahuluan}

Perkawinan menurut hukum adat merupakan peristiwa penting dan sakral bagi setiap orang yang menjalani tidak hanya para pihak yang menikah, tetapi juga masing-masing keluarga kedua mempelai bahkan menyangkut arwah para leluhur ${ }^{1}$. Bushar Muhammad berpendapat, di Indonesia norma hukum tidak tertulis tertuang dalam Hukum Adat yang merupakan hukum yang mengatur tingkah laku manusia yang dipertahankan dan sanksi adat atas pelanggaran yang ditetapkan oleh keputusan para penguasa adat yang memiliki kewibawaan ${ }^{2}$. Bangsa Indonesia itu sendiri merupakan bangsa yang kaya dimana terdapat berbagai suku dan budaya di dalamnya yang meyebabkan hukum adat yang berlaku di tiap-tiap daerah juga berbeda sebagaimana tertulis dalam Undang-Undang Dasar 1945 Pasal 18 B ayat (2) ${ }^{3}$. Salah satu Hukum Adat yang ada di Indonesia adalah Hukum Adat Suku Dayak. Perkawinan menurut Hukum Adat bukan hanya terkait dengan hubungan keperdataan saja tetapi memiliki pengertian lebih yaitu menekankan tentang kesepakatan dan erat sekali dengan rasa kekeluargaan, adat istiadat, dan keagamaan dalam pelaksanaannya ${ }^{4}$.

Pada masyarakat adat Suku Dayak melalui Peraturan Daerah Provinsi Kalimantan Tengah Nomor 16 Tahun 2008 Pasal 1 tentang Kelembagaan Adat Dayak di Kalimantan Tengah, dijelaskan bahwa Kedamangan adalah lembaga yang memiliki wilayah adat, kesatuan masyarakat adat, dan hukum adat dalam wilayah Provinsi Kalimantan Tengah yang terdiri dari himpunan beberapa Desa/ Kelurahan/ Kecamatan/Kabupaten yang tidak dapat dipisahkan ${ }^{5}$. Pada tingkat Kecamatan, Lembaga Kedamangan dibantu oleh para Mantir Adat yang menurut Peraturan Daerah Nomor 16 Tahun 2008 dibentuk dan diposisikan untuk mendukung pelestarian, pengembangan dan pemberdayaan

1 Wignjodipoero Soerojo, Pengantar Dan Asas-Asas Hukum Adat (Jakarta: PT. Gunung Agung, 1984). h. 122.

2 C.Dewi Wulansari, Hukum Adat Indonesia (Bandung: PT Refika Aditama, 2016).h. 5.

3 Undang-Undang Dasar 1945.

4 H.Hilman Hadikusuma, Hukum Perkawinan Indonesia (Bandung: Mandar Maju, 2007). h. 30.

5 Peraturan Daerah Provinsi Kalimantan Tengah Nomor 16 Tahun 2008 Tentang Kelembagaan Adat

Dayak Di Kalimantan Tengah, 2008. 
masyarakat adat suku Dayak yang dalam implementasinya Lembaga Kedamangan berfungsi sebagai tempat untuk menyelesaikan permasalahan adat dan dalam hal ini termasuk juga kasus perceraian masyarakat adat. 6

Peran dari Lembaga Adat sangat penting dalam hal penyelesaian kasus perceraian. Perceraian merupakan sebuah peristiwa yang harus diselesaikan dengan baik karena adanya pelanggaran-pelanggaran yang menggangu keseimbangan dan menjadi latar belakangi peristiwa tersebut di dalam rumah tangga masing-masing pihak ${ }^{7}$. Perlu dilakukan sebuah proses dan tahapan dalam melaksanakan perceraian adat sehingga menciptakan keseimbangan kembali dikarenakan sebuah peristiwa perceraian memiliki faktor-faktor penyebab yang terkait dengan pelanggaran-pelangaran hukum adat dalam rumah tangga pihak-pihak yang terkait. Perkawinan seperti halnya pada masyarakat adat tidak jarang dihadapkan pada masalah-masalah yang dapat menimbulkan terjadinya perceraian sebagai contoh hadirnya orang ketiga atau perselingkuhan 8 . Adanya perselingkuhan yang merupakan salah satu faktor penyebab perceraian perlu diselesaikan dengan baik, karena dianggap merupakan peristiwa yang merugikan serta dapat mengganggu keseimbangan dan keselarasan masyarakat adat yang sangat erat kaitannya dengan masyarakat adat itu sendiri ${ }^{~}$. Pelanggaran ini terjadi karena sejatinya makna perkawinan menurut hukum adat masyarakat Adat Dayak terdapat perjanjian dan kesepakatan kedua mempelai yang dikenal dengan Surat Perjanjian Pemenuhan Jalan Adat Menurut Adat Dayak Ngaju Kalimantan Tengah dengan tujuan untuk membentuk rumah tangga yang kekal dan bahagia. Hukum Adat Dayak memandang perkawinan merupakan sesuatu yang sakral karena tidak hanya menyangkut kedua belah pihak dan berfungsi untuk memungkinkan pertumbuhan tertib-teratur dari paguyuban hidup ke dalam generasi-generasi baru yang selanjutnya perkawinan tersebut juga mempertahankan kehidupan persekutuan setempat/masyarakat setempat selaku kesatuan tata-susunan rakyat. ${ }^{10}$

Perceraian secara Hukum Adat merupakan langkah terakhir yang harus ditempuh oleh pihak yang mengalami permasalahan dalam rumah tangganya seringkali mengalami kendala dalam pelaksanaannya. Banyak pasangan yang memiliki masalah dalam rumah tangganya membiarkan status perkawinannya terkatung-katung dan tidak memiliki status yang jelas. Hal tersebut tentu sangat merugikan, tidak hanya bagi salah satu pasangan melainkan juga bagi anak-anak pasangan tersebut. Kurangnya wawasan dan pengetahuan akan informasi mengenai langkah apa yang harus ditempuh serta peran Damang Kepala Adat dalam menyelesaikan kasus perceraian merupakan hal yang sangat merugikan. Berdasarkan uraian tersebut, maka melalui tulisan ini akan menganalisis sejauh mana kewenangan yang dimiliki oleh Damang Kepala Adat dalam

6 Peraturan Daerah Provinsi Kalimantan Tengah Nomor 16 Tahun 2008 Tentang Kelembagaan Adat Dayak Di Kalimantan Tengah.

7 Asliani Harahap, 'Pembaharuan Hukum Pidana Berbasis Hukum Adat', Jurnal EduTech, 4 (2) (2018) <https://doi.org/https://doi.org/10.30596/edutech.v4i2.2268>.h. 7.

8 Tolib Setiady, Intisari Hukum Adat Indonesia, ed. by Riduwan (Bandung: Alfabeta, 2009). h.268.

9 Eka Susylawati, 'Eksistensi Hukum Adat Dalam Sistem Hukum Di Indonesia', Jurnal Hukum Dan Pranata Sosial, 4 (1) (2009), 130 <https://doi.org/https://doi.org/10.19105/allhkam.v4i1.267>.h. 130.

10 Putri Fransiska Purnama Pratiwi, Suprayitno, and Triyani, 'Upaya Hukum Untuk Menjerat Tindakan Pelakor Dalam Perspektif Hukum Adat Dayak Ngaju', Jurnal Cakrawala Hukum, 10 No.2 (2019), hlm.210 <https://doi.org/https://doi.org/10.26905/>. 
menyelesaikan kasus perceraian serta bertujuan untuk mengkaji kepastian hukum terhadap Keputusan Damang Kepala Adat bagi para pihak sekaligus dapat memberikan wawasan terkait dengan penanganan yang tepat terhadap kasus perceraian pada masyarakat Adat Dayak khususnya, mahasiswa serta masyarakat luas.

\section{Metode Penelitian}

Metode Penelitian yang digunakan dalam penulisan artikel ini adalah Yuridis Empiris dan menggunakan pendekatan kualitatif, dimana lebih menekankan deksriptif dan analisis pada masalah dalam pembahasannya terkait dengan kewenangan Damang Kepala Adat dalam hal ini menyelesaikan kasus perceraian secara Hukum Adat Dayak dilihat dari suatu aturan hukum yang berlaku, prinsip hukum berdasarkan Peraturan Daerah Provinsi Kalimantan Tengah Nomor 16 Tahun 2008 tentang Kelembagaan Adat Dayak di Kalimantan Tengah dan menganalisis kepastian hukum keputusan Damang Kepala Adat dalam menyelesaikan kasus perceraian secara Hukum Adat bagi para pihak. Melihat dari kurangnya informasi ilmiah terkait dengan proses penyelesaian kasus perceraian pada masyarakat Adat Dayak Ngaju sehingga penelitian ini bertujuan untuk memberikan tambahan informasi dan wawasan yang bermanfaat bagi kalangan masyarakat adat dan umum. Teknik pengumpulan data dilakukan metode wawancara dan dokumen yang diberikan oleh Damang Kepala Adat. Kemudian kemudian dari hasil tersebut penulis melakukan analisis dengan teknik deskriptif kualitatif dan didukung dengan literatur dan perundang-undangan yang relevan dengan penelitan.

\section{Hasil dan Pembahasan}

\subsection{Kewenangan Damang Kepala Adat dalam Menyelesaikan Kasus Perceraian pada Masyarakat Hukum Adat di Kalimantan Tengah}

Kehidupan masyarakat hukum adat tidak terlepas dari adanya permasalahan yang timbul dalam hubungan manusia satu dengan manusia lainnya, dalam hal ini adalah perceraian. Upaya dalam menyelesaikan kasus perceraian memerlukan adanya pembagian tugas kepimimpinan guna mengatur norma-norma kehidupan dalam tatanan hukum adat. Terkait dengan hal tersebut, muncul lembaga adat untuk menjaga dan mengawasi aturan norma-norma yang hidup dalam kehidupan masyarakat adat 11 . Adapun terkait dengan kewenangan Lembaga Adat dalam hal menyelesaikan permasalahan adat sesuai dengan Teori Kewenangan, dimana pengertian dari wewenang menurut Kamus Besar Bahasa Indonesia adalah hak dan kekuasaan untuk bertindak, memerintah ${ }^{12}$. Terkait dengan teori kewenangan tersebut, Lembaga adat sangat berperan penting dalam mengatur pola tingkah laku masyarakat adat, terutama masyarakat adat Dayak dan dibantu oleh let adat atau pengurus adat dalam menyelesaikan permasalahan adat dalam hal ini perceraian ${ }^{13}$. Kewenangan ini berdasar

11 Lastuti Abubakar, 'Revitalisasi Hukum Adat Sebagai Sumber Hukum Dalam Membangun Sistem Hukum Indonesia', Dinamika Hukum, 13 (2) (2013), 320-31 <http://www.dinamikahukum.fh.unsoed.ac.id/index.php/JDH/article/view/213/161>.

12 'Kamus Besar Bahasa Indonesia' <https://jagokata.com/arti-kata/wewenang.html \#: :text=\%5Bwewenang\%5D Makna wewenang di KBBI,arti dan definisi di jagokata.>.

13 Dewan Adat Dayak, Pedoman Peradilan Adat Dayak Kalimantan Tengah, 2015. 
pada Pasal 18b Undang-Undang Dasar 1945 yang menunjukan eksistensi dari hukum adat melalui Peradilan Adat bagi para pihak yang melanggar ${ }^{14}$.

Penyelesaian kasus Perceraian merupakan wewenang bagi Let Adat untuk dilaksanakan, hal ini tertera pada Pasal 10 Peraturan Daerah Kalimantan Tengah No. 16 Tahun 2008, dimana Damang Kepala Adat mempunyai hak dan wewenang melaksanakan perkawinan secara adat, mengesahkan surat perjanjian perkawinan secara adat, mengeluarkan surat keterangan perceraian secara adat dan surat-surat lainnya yang berkaitan dengan hukum adat sepanjang diminta oleh pihak-pihak yang berkepentingan. ${ }^{15}$ Kewenangan dalam hal mengatur, mengurus dan menyelesaikan kehidupan dalam masyarakat adat juga diatur dalam ketentuan Pasal 1 ayat 15 Peraturan Menteri Dalam Negeri Nomor 5 Tahun 2007 tentang Pedoman Lembaga Kemasyarakatan, dimana permasalahan perceraian masyarakat adat merupakan kewenangan dari Lembaga Adat 16. Damang Kepala Adat merupakan orang yang merumuskan dan melestarikan budaya serta adat istiadat masyarakat adat, oleh karenanya orang-orang yang duduk dalam organisasi itu harus benar-benar memahami seluk beluk hukum adat, permasalahan adat serta sanksi yang dijatuhkan. Let adat dalam masyarakat adat Dayak, terdapat struktur kepengurusan yang berhubungan dengan otoritas kekuasaan dan wewenang. Tingkat kecamatan dikenal dengan kedamangan yang dipimpin oleh seorang Damang Kepala Adat. Adapun dalam tingkat desa dikenal Mantir adat yang memiliki wewenang untuk menyelesaikan permasalahan adat pada tingkat desa. Adapun dari ke semua aturan memiliki hubungan yang erat dalam hal penyelesaian segala bentuk permasalahan dalam rumah tangga dan tidak saling bertentangan satu sama lain karena melalui Peraturan Menteri telah menjelaskan sebagaimana penjelasan diatas dan dilanjutkan secara rinci melalui Perdaturan Daerah Kalimantan Tengah terkait dengan Tugas dan Kewenangan Lembaga Adat.

Hal yang melatar belakangi putusnya perkawinan dalam hal ini terkait dengan putusnya perkawinan karena perceraian. Menurut Hilman Hadikusuma, perceraian adalah perpisahan atau perihal bercerai antara suami dan istri, perceraian juga berarti putusnya ikatan tali perkawinan antara suami dan istri yang telah dibina atau berlangsung sehingga menimbulkan keretakan dalam rumah tangga dengan demikian ke dua belah pihak menjadi insan yang hidup masing-masing ${ }^{17}$. Pada Masyarakat Adat, perselisihan dan ketidakcocokan dalam rumah tangga yang menjadi penyebab atau alasan terjadinya perceraian. Sama halnya dengan faktor penyebab putusnya perkawinan menurut Pasal 39 Undang-Undang Nomor 1 Tahun 1974 adalah perceraian dimana terdapat penyebabnya yaitu : 18

a. Salah satu pihak berbuat zina atau menjadi pemabuk, pemadat, penjudi dan lain sebagainya yang susah ditentukan

b. Salah satu pihak meninggalkan yang lain selama dua tahun berturut-turut tanpa alasan yang sah atau karena hal lain di luar kemampuannya

14 Dewan Adat Dayak, Pedoman Peradilan Adat Dayak Kalimantan Tengah, 2015.

15 Peraturan Daerah Provinsi Kalimantan Tengah Nomor 16 Tahun 2008 Tentang Kelembagaan Adat Dayak Di Kalimantan Tengah.

16 Peraturan Menteri Dalam Negeri Nomor 5 Tahun 2007, 2007.

17 Hilman Hadikusuma, Hukum Perkawinan Adat Dengan Adat Istiadat Dan Upacara Adatnya (Bandung: PT Citra Aditnya Bakti, 2003).

18 Undang-Undang Nomor 1 Tahun 1974 Tentang Perkawinan. 
c. Salah satu pihak mendapatkan hukuman penjara selama 5 (lima) tahun atau hukuman yang lebih berat setelah perkawinan berlangsung

d. Salah satu pihak mendapatkan cacat badan atau penyakit yang mengakibatkan tidak dapat menjalankan kewajibannya sebagai suami istri

e. Salah satu pihak melakukan kekejaman atau penganiayaan berat yang membahayakan terhadap pihak lain

f. Antara suami istri terlibat pertengkaran dan terus menerus dan tidak ada harapan akan hidup rukun dalam rumah tangga.

Perceraian yang merupakan kasus yang berdimensi perdata dalam Hukum Nasional sifatnya sama dimuka Peradilan Adat dan penanganan kasus baik berdimensi perdata maupun pidana difokuskan untuk mendamaikan para pihak. Setiap perkara yang menjadi aduan dilakukan upaya perdamaian sebelum masuk ke Peradilan Adat. Para pemangku adat akan berupaya untuk melakukan mediasi agar pihak yang berperkara dapat bernegosiasi atau bermusyawarah dalam menyelesaikan masalah mereka 19. Kedamangan merupakan kekuasaan tertinggi yang diberi wewenang untuk memutuskan segala jenis perkara pada masyarakat adat Dayak. ${ }^{20}$

Damang memiliki pedoman peradilan Hukum Adat yang berisi tata cara dalam menyelesaikan sebuah permasalahan. Tahapan dalam Persidangan Adat dapat berbeda antara satu dengan yang lain, bahkan tidak jarang proses-proses peradilan adat antara satu daerah dengan daerah lain diselenggarakan dengan upacara-upacara adat yang berbeda. Namun hal tersebut tidak menjadi masalah, dengan adanya pedoman peradilan adat tidak bermasud untuk menyeragamkan, melainkan memberikan pemahaman bagi para pemangku adat dalam tahapan-tahapan yang harus dilalui. Adapun tahapan-tahapan tersebut adalah: ${ }^{21}$

1. Adanya laporan dari Mandawa yaitu korban atau anggota keluarga yang merasa dirugikan yang menjadi dasar Damang Kepala Adat untuk membawa kasus itu ke proses peradilan adat.

2. Tahap pertama ini para pihak harus sudah menyiapkan bukti dan saksi.

3. Damang meminta para pihak membuat surat pernyataan bahwa mereka memilih secara bebas untuk menyelesaikan masalah itu melalui Peradilan Adat. Pernyataan ini dilakukan secara tertulis bermaterai. Jika para pihak setuju memilih Peradilan Adat maka mantir atau damang sebagai mediator atau negosiator mengajukan perdamaian dan pelapor diwajibkan menyediakan beberapa benda adat sebagai tanda bukti kepatuhannya sesuai dengan peraturan kedamangan.

4. Pemberitahuan kepada para pihak bahwa Peradilan Adat akan digelar, Hakim Adat akan mengundang seluruh anggotanya untuk membahas laporan dari pihak Mandawa. Dalam pertemuan ini, akan diputuskan kapan waktu yang tepat untuk memanggil pihak yang berperkara dan terutama mendatangkan Tandawa (pihak terlapor) untuk memulai proses persidangan,

19 Gindo L Tobing, 'Hukum Adat Sebagai Pranata Umum Penyelesaian Perselisihan Melalui Musyawarah Mufakat Dalam Lingkungan Masyarakat', Jurnal Hukum To-Ra, 2 (2016), 409 <http://ejournal.uki.ac.id/index.php/tora/article/view/1105/932>.

20 Dewan Adat Dayak, Pedoman Peradilan Adat Dayak Kalimantan Tengah.

21 Dewan Adat Dayak, Pedoman Peradilan Adat Dayak Kalimantan Tengah. h.39. 
5. Hakim Adat memanggil para pihak baik mandawa maupun tandawa supaya hadir memenuhi panggilan. Hakim Adat mulai bertanya kepada pihak penuntut tentang duduk perkara dan kepada pelanggar tentang kebenaran gugatan penuntut kepadanya.

6. Tahap kelima, setelah para pihak baik mandawa maupun tandawa hadir, sebelum memasuki pokok perkara, Mantir Let Adat atau Damang selaku hakim adat menawarkan sekali lagi perdamaian dengan berbagai alasan yang cukup jika perkara itu dibuka. Jika kedua belah pihak menerima tawaran berdamai, maka Mantir membuat akta perdamaian jika sudah di tingkat damang, maka damang membuat keputusan perdamaian yang ditandatangani oleh kedua pihak serta pernyataan untuk tidak mengulangi perbuatan yang salah di atas materai.

7. Tahap keenam, jika para pihak tetap tidak mau berdamai, maka Hakim Adat membuka sidang dengan membacakan gugatan mandawa dan kepada tandawa untuk memberi keterangan bantahan terhadap gugatan mandawa. Pihak mandawa yang memberi keterangan gugatan maupun pihak tandawa yang membantah dakwaan supaya diikuti dengan bukti-bukti dan saksi-saksi

8. Tahap ketujuh, setelah bukti-bukti dan saksi-saksi memberi keterangan, maka mantir atau damang wajib menguji kebenaran bukti atau saksi, dengan demikian proses Peradilan Adat berlangsung secara terbuka, jujur dan bertanggung jawab sehingga keadilan dapat diperoleh para pihak yang berperkara

9. Tahap kedelapan, jika terdapat hal-hal yang menghalangi untuk mendatangkan saksi, maka mantir atau damang dapat meminta bantuan Batamad dan biaya ditanggung oleh pihak yang membutuhkan keterangan saksi tersebut

10. Tahap ke sembilan, setelah mendengar semua keterangan saksi dan bukti-bukti, Damang dan Mantir Adat melakukan musyawarah untuk membuat keputusan. Pada saat musyawarah berlangsung, para Pemangku Adat juga bisa melibatkan tokoh-tokoh adat lainnya baik laki-laki maupun perempuan

11. Tahap kesepuluh, setelah musyawarah dan membuat keputusan, tahap akhir dari proses peradilan adat adalah pengumuman keputusan. Pengumuman ini wajib dihadiri para pihak, para saksi, tokoh-tokoh masyarakat laki-laki dan/atau perempuan. Pembacaan keputusan dilaksanakan dalam sidang yang terbuka untuk umum. Pihak yang dinyatakan bersalah dikenai singer, besarannya disesuaikan dengan peraturan masing-masing damang. Sebagai bagian dari upaya untuk memperkuat peran Peradilan Adat, maka keputusan penyelesaian perkara itu dicatatkan dan diarsipkan dalam sebuah buku induk registrasi perkara adat.

12. Tahap kesebelas, jika semua pihak telah sepakat dan menerima Putusan Hakim Adat, maka dilaksanakan di rumah Damang atau Mantir Let Adat atau di Balai Adat yang dihadiri oleh kedua belah pihak dan para tokoh adat. Kehadiran para tokoh adat bertindak sebagai saksi bahwa keputusan hakim peradilan adat telah dilaksanakan.

13. Tahap keduabelas, pelaksanaan keputusan hakim ini diakhiri dengan upacara adat, sesuai dengan peraturan damang masing-masing.

14. Tahap-tahap diatas dapat dipersingkat sesuai kebutuhan setiap Kedamangan.

Perkawinan yang dilakukan secara Hukum Adat jika terjadi perceraian maka diselesaikan melalui Hukum Adat sesuai dengantata cara yang berlaku. Negara 
mengatur secara Nasional terkait dengan perkawinan melalui Undang-Undang Nomor 1 Tahun 1974, namun tidaklah mengatur mengenai hal-hal yang berhubungan dengan bentuk-bentuk perkawinan, peminangan, upacara-upacara perkawinan yang merupakan ruang lingkup dari Hukum Adat yang masih dilangsungkan oleh masyarakat Indonesia 22 . dengan demikian negara tidak memiliki kewenangan dalam memutuskan perkawinan yang dilakukan secara hukum adat.

Kewenangan Damang Kepala Adat dalam menyelesaikan kasus perceraian masyarakat adat adalah dari adanya laporan dari Pelapor yang kemudian berdasarkan pedoman peradilan adat Dayak diselenggarakan peradilan untuk meluruskan keinginan dari masing-masing pihak untuk bercerai. Sesuai dengan corak dalam Hukum Adat Indonesia, dimana ada musyawarah mufakat. Hukum adat mengutamakan adanya musyawarah mufakat di dalam keluarga baik untuk memulai maupun mengakhiri pekerjaan apalagi yang bersifat peradilan dalam menyelesaikan perselisihan antara satu dengan yang lainnya 23. Adapun musyawarah mufakat ini juga merupakan implementasi dari sila ke-4 (keempat) Pancasila yang terdapat dalam pelaksanaan dalam menyelesaikan permasalahan dimana dibutuhkan itikad baik dari para pihak dan adanya semangat yang adil dan bijaksana dari orang yang dipercayakan sebagai penengah dalam hal ini Damang Kepala Adat. Damang Kepala Adat dalam hal kasus perceraian bersifat menunggu, dalam artian adanya proses karena adanya laporan dari si Pelapor untuk meminta penyelesaian kasus perceraiannya oleh Damang. Kewenangan Damang Kepala Adat dalam proses perceraian adalah meluruskan niatan dari Pihak Pelapor untuk mengakhiri ikatan perkawinannya dengan mengeluarkan Surat Keputusan oleh Damang dengan mengeluarkan Surat Keputusan kasus perceraian. Adapun maksud dari hal ini adalah karena para pihak yang membuat pernyataan yang kemudian surat pernyataan kedua belah pihak itulah yang menjadi dasar berakhirnya ikatan perkawinan antara kedua belah pihak. Surat pernyataan dibuat oleh kedua belah pihak, baik istri maupun suami. Adapun isi dari surat pernyataan tersebut adalah identitas para pihak, alasan perceraian, tanggal dan tanda tangan masing-masing pihak diatas materai. Damang Kepala Adat berwenang dalam memegang dan membuat aturan di wilayah kedamangan terpilih untuk menjaga, melindungi, melayani masyarakat yang ada di wilayah kedamangan serta bertugas menegakkan hukum adat.

\subsection{Kepastian Hukum Keputusan Damang Kepala Adat dalam Menyelesaikan Kasus Perceraian Secara Hukum Adat}

Penyelesaian kasus perceraian oleh Damang Kepala Adat secara Hukum Adat Dayak adalah menciptakan harmonisasi sosial, keadilan yang diharapkan oleh kedua belah pihak dan masyarakat hukum adat ${ }^{24}$. Dikutip dari Teori Keputusan yang dikemukakan oleh Ter Har Bzn, bahwa hukum adat merupakan keputusan-keputusan dari Kepala Adat, hal ini senada dengan peran Damang Kepala Adat dalam membuat Keputusan

22 Setiady. h. 224.

23 Laurensius Arliman, 'Hukum Adat Indonesia Dalam Pandangan Para Ahli Dan Konsep Pemberlakuannya Di Indonesia', Jurnal Selat, 5 (2) (2018), 179-90 <https://doi.org/https://doi.org/10.31629/selat.v5i2.320>.

24 I Made Kastama, 'Hukum Adat Dayak: Bentuk, Penerapan Dan Sanksi Singer Di Desa Pandreh Kecamatan Teweh Tengah Kabupaten Barito Utara', Belom Bahadat, VIII (2018) <https://doi.org/https://doi.org/10.33363/bb.v8i2.206>.h. 3. 
terkait dengan kasus perceraian secara hukum adat dan mengungkapkan bahwa Hukum Adat mencakup aturan-aturan yang dibuat oleh keputusan-keputusan para pejabat yang memiliki kewibawaan atau pengaruh dan serta merta harus dipatuhi dan ditaati ${ }^{25}$.

Kewenangan dalam membuat Surat Keputusan Perceraian Hukum Adat Dayak Ngaju juga dimiliki oleh Kerapatan Mantir Perdamaian Adat pada tingkat Desa/Kelurahan seperti tertera pada Pasal 32 Peraturan Daerah Provinsi Kalimantan Tengah Nomor 16 Tahun 2008, namun dalam penelitian ini lebih memfokuskan kewenangan memutus perkawinan oleh Damang Kepala Adat. Dikaitkan dengan kasus perceraian masyarakat adat Dayak, keputusan yang buat oleh Damang Kepala Adat atas segala perselisihan, sengketa dan pelanggaran hukum adat yang telah didamaikan dan diberi sanksi adat melalui keputusan Damang Kepala Adat tingkat Kecamatan, adalah bersifat final dan mengikat. Adapun makna dari hal tersebut berarti Damang Kepala Adat merupakan pejabat yang dianggap memiliki kewibawaan dan pengaruh dalam menyelesaikan suatu permasalahan dalan hal ini perceraian, memiliki peran yang sangat penting dalam terciptanya perdamaian melalui keputusan yang dibuat. Perdamaian dalam hal ini bukan tercapainya perdamaian disaat mediasi, namun jalan perceraian juga dianggap solusi dalam mengakhiri prahara dalam rumah tangga sehingga membawa perdamaian bagi para pihak untuk dapat melanjutkan kehidupan mereka. Dikeluarkannya Surat Keputusan yang dikeluarkan oleh Lembaga Kedamangan Adat sebagai legalitas sekaligus menerangkan bahwa kedua pihak tersebut telah bercerai secara Hukum Adat.

Pada kasus perceraian menurut hukum adat pada dasarnya menjadikan perjanjian kawin sebagai acuan Damang dalam membuat keputusan. Perjanjian kawin yang dibuat atau yang dikenal dengan Surat Perjanjian Pemenuhan Jalan Adat Menurut Adat Dayak Ngaju memuat secara rinci hal-hal yang menjadi kesepakatan kedua belah mempelai termasuk mengatur mengenai putusnya perkawinan. Perjanjian kawin ini merupakan hal yang penting karena memuat hal-hal yang bersifat kosmis dimana manusia satu tidak bisa dipisahkan dengan manusia lainnya dan kaitannya dengan alam gaib yang melambangkan kesungguhan dari kedua belah pihak sebelum melaksanakan perkawinan ${ }^{26}$. Seperti ada di dalam nya memuat tentang jujur atau palaku yang diberikan oleh pihak pria kepada pihak wanita sebagai syarat sah perkawinan menurut Hukum Adat. 27

Perkawinan Adat Dayak yang didasari oleh kesepakatan yang tertuang dalam dengan Surat Perjanjian Pemenuhan Jalan Hadat (Adat) Menurut Adat Dayak Ngaju, juga mengatur terkait dengan ikatan yang memiliki dasar dan bernilai luhur dan suci. Hadat (Adat) berarti sesuatu perbuatan hukum, etika,dsb yang lazim diturut atau dilakukan

25 Hilman Hadikusuma, Pokok-Pokok Pengertian Hukum Adat (Bandung: Alumni, 1980).h. 8.

26 Harmaini and Febrian Chandra, 'Selayang Pandang Hukum Adat Di Kabupaten Merangin (Kajian Masyarakat Hukum Adat)', Adil Jurnal Hukum STIH YPM, 2 (2020), 34 <http://adil.stihypm.ac.id/index.php/ojs/article/view/9/11>.

27 Darwis Luther Rampai, 'Perkawinan Menurut Hukum Adat Dayak Ngaju Kalimantan Tengah Ditinjau Dari Undang-Undang Nomor 1 Tahun 1974' (Universitas Airlangga, 2003) <http:// repository.unair.ac.id/35031/12/jiptunair-gdl-s2-2004-rampay2c-1042-perkawinanth_29-03.pdf $>$. 
sejak dahulu kala. ${ }^{28}$ Jalan Hadat tersebut yang akan dilaksanakan pada saat acara perkawinan adat yang terdiri dari: ${ }^{29}$

1. Mas Kawin atau yang lebih dikenal dengan istilah Palaku yang memiliki makna bahwa laki-laki dan perempuan tersebut telah memiliki ikatan dan menjadi pasangan yang sah dihadapan keluarga. Palaku merupakan syarat mutlak dalam perkawinan adat Dayak karena merupakan dasar dari sebuah perkawinan atau dalam istilah Dayak Ngaju disebut dengan Galang Pambelum. Palaku ini sebagai simbol sebagai jaminan bagi pihak wanita yang diberikan oleh pihak laki-laki dalam membina rumah tangga yang pada jaman sekarang berupa sebidang tanah atau barang berharga yang tidak boleh dipindah tangankan dan dijual.

2. Penghargaan yang diberikan kepada saudara laki-laki mempelai wanita atau yang dikenal dengan istilah Saput. Saput diberikan sebagai simbol terimakasih kepada sudara laki-laki mempelai wanita yang telah menjaga mempelai wanita selama ini sebelum memasuki jenjang perkawinan dan sekaligus memberikan restu perkawinan. Makna saput disini juga bahwa mempelai laki-laki akan mengayomi dan menghormati saudara-saudara mempelai wanita seperti keluarganya sendiri.

3. Selain penghargaan terhadap saudara laki-laki mempelai wanita, penghargaan juga diberikan kepada orang tua mempelai wanita dengan memberikan kain atau pakaian sebagai simbol bahwa dalam pernikahan ini tidak hanya mengambil sang wanita sebagai istri melainkan menerima orang tuanya juga sebagai bagian dari keluarga untuk dihormati layaknya orang tua sendiri. Simbol penghargaan ini disebut dengan Pakaian Sinde Mendeng.

4. Sang ibu dari mempelai wanita merupakan sosok yang penting dalam kehidupan mempelai wanita karena sudah melahirkan, merawat serta membesarkan mempelai wanita hingga dewasa dan memasuki jenjang perkawinan. Simbol penghargaan bagi sosok ibu dalam perkawinan adat Dayak disebut dengan Sinjang Entang yaitu kain panjang untuk menggendong bayi yang melambangkan cinta kasih seorang ibu kepada anaknya dan cinta kasih terhadap kehidupan baru yang akan dijalani oleh mempelai wanita dalam membina rumah tangga .

5. Penghormatan dalam pelaksanaan perkawinan adat kepada para Mantir dan Mantir Pelek sebagai perantara yang bertugas yaitu dengan memberikan Lapik Luang yang berupa kain panjang dan tikar rotan yang berfungsi sebagai Sangku Pelek atau alas. Ucapan terimakasih mempelai dalam rangkaian acara perkawinan juga pada saat Haluang Hapelek dengan memberikan Mangkok Luang yang berisi beras dimana memiliki makna bahwa acara tersebut sangat sakral.

6. Melindungi kedua mempelai dari Pali Dahiyang Baya atau bahaya dapat dilakukan dengan melakukan ritual Tutup Uwan yang disimbolkan dengan kain hitam yang diberikan kepada nenek mempelai wanita. Simbol ini bermakna dalam menjalani bahtera rumah tangga segala keburukan ditutupi oleh Tutup Uwan tersebut yang niscaya akan melindungi kedua mempelai dari hal buruk dalam pernikahan.

28 Bajik Rubuh Simpei and others, Kamus Pengantar Ngaju-Indonesia (Palangka Raya: PT Sinar Bagawan Khatulistiwa, 2016).

29 'Prosesi Pernikahan Adat Dayak Ngaju Di Kalimantan Tengah', Gpswisataindonesia, 2017 <https://gpswisataindonesia.info/2017/01/prosesi-pernikahan-adat-dayak-ngajukalimantan-tengah-ngaju/>. 
7. Rumah tangga yang akan dijalani oleh kedua mempelai juga harus kuat dan kokoh. Hal tersebut diperoleh melalui ritual Duit Lapik Ruji yang secara simbolis adalah uang logam perak Belanda yang diyakini akan mendatangkan banyak rejeki yang baik bagi rumah tangga kedua mempelai.

8. Bagi mempelai yang telah terikat dalam pernikahan maka secara sah telah membentuk keluarga yang baru. Secara simbolis disebut dengan Bulau Singah Pelek atau Cincin kawin. Bulau Singah Pelek adalah berupa emas yang diibaratkan kemurnian cinta kasih kedua mempelai dan tidak pernah luntur dan bertujuan agar rumah tangga yang baru terbentuk tidak mengalami ketersesatan dalam menjalani kehidupan barunya. Bisa berjalan dengan bahagia dan terhindar hari hal-hal yang buruk juga harmonis "Nyamah Hentang Tulang Ije Sandung Mentang".

9. Simbolis uang logam atas dasar kesepakatan kedua mempelai terkait dengan besarannya disebut dengan Duit Turus atau Timbuk Tangga, dimana memiliki makna bahwa telah terjadinya sebuah pernikahan. Duit Turus sebagai saksi terjadinya pernikahan tersebut yang diberikan kepada kedua orang tua mempelai. Dengan adanya saksi dalam pernikahan maka sekaligus mengindarkan keduanya mendapat anggapan yang tidak baik karena adanya kebersamaan dalam keseharian. Saksi yang dalam hal ini si penerima Duit Turus yakni orang tua juga bisa bermakna memohon doa restu kepada orang tua untuk kelancaran dalam membina kehidupan rumah tangga.

10. Perkawinan yang bahagia merupakan hal yang diharapkan oleh para mempelai yang dalam perkawinan adat Dayak terdapat smbol yang melambangkan hal tersebut yaitu Garantung Kuluk Pelek. Simbol ini juga melambangkan kewibawaan mempelai pria sebagai seorang suami dalam membila keluarga. Secara simbolis, Garantung Kuluk Pelek adalah sebuah Gong. Gong pada perkawinan masyarakat Dayak memiliki makna yang dalam akan arti penting sebuah perkawinan yang senantiasa harus dijaga dalam membangun rumah tangga yang bahagia

11. Lamiang yang atau dengan nama lain disebut dengan Manik Batu Agate adalah salah satu syarat yang harus ada dalam perkawinan adat Dayak. Melambangkan ketulusan, cinta kasih, saling menyayangi satu sama lain dan sebagai tonggak awal dalam perkawinan. Hal ini supaya dalam perjalannya berumah tangga jika dihadapkan pada situasi yang sulit maka mempelai akan saling membantu satu sama lain. Lamiang mutlak ada dalam perkawinan adat Dayak.

12. Perkawinan yang telah disatukan kedalam ikatan perkawinan adat bagi kedua mempelai menjadikan kedua insan menjadi satu dalam berbagi rasa dan tanggung jawab dalam kehdupan yang baru, seperangkat Pinggan Pananam Pahanjean Kuman atau seperangkat peralatan makan merupakan simbol dari rejeki yang berlimpah untuk bersama-sama membangun rumah tangga dan hal tersebut yang harus ada dalam acara perkawinan adat Dayak.

13. Seperangkat tempat tidur yang disebut dengan istilah Jangkut Amak memiliki makna dalam perkawinan tersebut adalah kehidupan baru bagi kedua mempelai dalam membangun rumah tangga.

14. Pada acara Haluang Hapelek dalam rangkaian acara perkawinan adat, kepada para hadirin undangan yang hadir disuguhi minuman tuak atau yang disebut Rapin Tuak. Minuman tuak dalam sebuah acara perkawinan memiliki makna kegemburaan akan adanya sebuah peristiwa yang berbahagia. 
15. Jamuan bagi para tamu undangan dalam perkawinan adat merupakan hal yang penting sama halnya dengan syarat-syarat lainnya. Para tamu undangan yang datang memberikan doa dan restu kepada kedua mempelai harus dijamu dengan baik. Persiapan ini memerlukan biaya yang disebut dengan Bulau Ngandung sebagai rasa syukur dan terimakasih kedua mempelai kepada Tuhan dan atas kehadiran dan doa restu yang diberikan.

16. Rentetan prosesi acara perkawinan selanjutnya adalah ngunduh mantu atau dalam istilah adat Dayak disebut dengan Pakaja Manantu. Pada acara ini secara simbolis adalah pemberian sesuatu hal yang berharga atau istilahnya disebut Batu Kaja yang biasanya merupakan kesepakatan yang biasanya adalah dalam bentuk emas murni. Pemberian barang simbolis ini diberikan oleh orang tua mempelai laki-laki kepada mempelai wanita sebagai ungkapan dan wujud rasa bahagia kepada wanita yang bersedia menjadi istri anaknya.

Melihat dari makna yang terkandung dalam perkawinan masyarakat adat Dayak tidak semata-mata hubungan antara pria dan wanita untuk mendapatkan keturunan saja melainkan menyangkut kerabat dan keluarga kedua belah pihak, mencerminkan sistem kekeluargaan masyarakat adat tertentu dan garis keturunan ${ }^{30}$. Melihat dari makna perkawinan Suku Dayak diatas, maka perceraian harusnya bukanlah suatu hal yang patut dilakukan. Jalan Hadat (Adat) dalam sebuah perkawinan memiliki makna yang mendalam dan mutlak dilakukan pada sebuah prosesi perkawinan. Tidak ada sebuah perkawinan adat Dayak jika tidak dilakukan Prosesi Jalan Hadat (Adat) yang selanjutnya dilakukan Perjanjian Kawin sebagai pengukuhan sebuah perkawinan adat Dayak. Perjanjian Kawin Adat atau yang disebut Perjanjian Pemenuhan Jalan Adat bermakna pengikat bagi para pihak yang melakukan perkawinan. Makna dari Jalan Hadat (Adat) ini adalah sebagai bentuk upaya yang dilakukan manusia dalam hubungannya dengan sesama, lingkungan dan Tuhan. Sesuai dengan pasal 7 Peraturan Daerah Kalimantan Tengah Nomor 8 Tahun 2008 tentang Kedudukan, Tugas dan Fungsi Damang Kepala Adat menjelaskan bahwa fungsi Damang adalah penegak dari hukum adat. Makna dari perjanjian kawin itu adalah hukum bagi kedua belah pihak yang membuatnya dan harus dilaksanakan. Semua point tersebut termuat dalam Surat Perjanjian Kawin termasuk dengan didalamnya mengatur tentang apabila dikemudian hari terjadi perceraian. Surat Perjanjian Kawin disepati dan ditandatangani oleh kedua belah pihak, orang tua, saksi-saksi, Kerapatan Mantir Adat dan Damang Kepala Adat.

Surat Keputusan Damang Kepala Adat memiliki kepastian hukum dimana para pihak wajib untuk melaksanakan keputusan tersebut karena didasari oleh kesepakatan. Prinsip dalam Keputusan Damang Kepala Adat adalah bersifat mengikat serta memiliki kekuatan eksekutorial bagi para pihak. Kekuatan Eksekutorial dalam Keputusan Damang Kepala Adat karena pada prinsipnya sifatnya hanya meluruskan niat para pihak untuk bercerai, dengan demikian secara hukum adat maka perkawinan tersebut dinyatakan berakhir dengan dikeluarkannya Surat Keputusan oleh Damang Kepala Adat. Prinsip menghormati keputusan peradilan adat adalah mutlak setelah dikeluarkan Keputusan Damang Kepala Adat melalui proses peradilan adat dan dinyatakan sah dan mengikat bagi para pihak merupakan wujud dari kepastian hukum yang diterima oleh para pihak dan harus dilaksanakan. ${ }^{31}$

30 Sirman Dahwal, Perbandingan Hukum Perkawinan (Bandung: CV. Mandar Maju, 2017).

31 Dewan Adat Dayak, Pedoman Peradilan Adat Dayak Kalimantan Tengah. h. 25. 
Keputusan Damang Kepala Adat dalam menyelesaikan sengketa perceraian tidak bersifat diktator justru memberikan keleluasaan bagi para pihak untuk mencari kepastian hukum dalam menyelesaikan masalahnya bila masih merasa keberatan ${ }^{32}$. Hal ini memberikan pengertian bahwa Damang selaku Kepala Adat tidak menentukan atau memutus sebuah perkawinan tanpa adanya permohonan, namun Keputusan yang dibuat oleh Damang berasal dari keinginan sendiri para pihak dan setelah berbagai tahapan maka diputuskan oleh Damang melalui Surat Keputusan yang berkekuatan hukum tetap. Pengaturan mengenai penyelesaian kasus perceraian secara Hukum Adat oleh Damang secara jelas tertuang dalam Peraturan Daerah Provinsi Kalimantan Tengah Nomor 16 Tahun 2008 tentang Kelembagaan Adat Dayak di Kalimantan Tengah. Hal ini menunjukan bahwa adanya pengakuan dari Negara melalui pemerintah setempat mengenai keberadaan suatu masyarakat adat yang juga memberikan kepastian hukum bagi para pihak yang menyelesaikan masalahnya melalui hukum adat 33 .

\section{Kesimpulan}

Penting bagi masyarakat untuk memiliki kepastian hukum terkait dengan perceraian. Hambatan yang dihadapi seperti kurangnya informasi dan wawasan terkait dengan kewenangan Damang Kepala Adat dalam menyelesaikan kasus perceraian tertuang dalam Peraturan Daerah Kalimantan Tengah Nomor 8 Tahun 2008 tentang Kedudukan, Tugas dan Fungsi Damang Kepala Adat. Damang Kepala Adat merupakan orang yang dipercaya oleh masyarakat yang memiliki kewibawaan dalam memutus perkara adat dan dalam hal ini perceraian. Terkait proses peradilan adat juga telah dijelaskan secara rinci dan dalam pelaksanaannya juga menggunakan Pedoman Peradilan Adat Dayak. Kewenangan yang dimiliki Damang Kepala Adat adalah mengupayakan perdamaian dalam menanggapi laporan perihal perceraian dan bila perdamaian tidak tercapai maka proses dilanjutkan dan diakhiri dengan dikeluarkannya Surat Keputusan yang berdasarkan kesepakatan para pihak. Keputusan yang dibuat oleh Damang Kepala Adat bersifat final dan mengikat bagi para pihak serta memiliki kepastian hukum bagi masing-masing pihak berdasarkan permohonan dari para pihak.

\section{Daftar Pustaka / Daftar Referensi}

\section{$\underline{\text { Buku }}$}

Dahwal, Sirman (2017). Perbandingan Hukum Perkawinan CV. Mandar Maju, Bandung. Hadikusuma, H. (2007). Hukum Perkawinan Indonesia Mandar Maju, Bandung.

Hadikusuma, H. (2003). Hukum Perkawinan Adat Dengan Adat Istiadat Dan Upacara Adatnya PT Citra Aditnya Bakti, Bandung.

Hadikusuma, H. (1980). Pokok-Pokok Pengertian Hukum Adat. Alumni, Bandung.

32 Ahyuni Yunus and Ahmad Ali Muddin, 'Penyelesaian Sengketa Tanah Ulayat Yang Telah Bersertifikat Berdasarkan Hukum Adat Malind-Anim', Kertha Patrika, 41(3) (2019), 206-21 <https://doi.org/10.24843/KP.2019.v41.i03.p03>.

33 Ilman Hadi, 'Kekuatan Hukum Putusan Adat', Hukum Online, 2012 <https://www.hukumonline.com/klinik/detail/ulasan/lt4fbb44750563e/kekuatanhukum-putusan-adat/>. 
Setiady, Tolib, (2009). Intisari Hukum Adat Indonesia, ed. by Riduwan, Alfabeta Bandung.

Simpei, Bajik Rubuh, Damianus Siyok, Sepmiwawalma, and Yankris (2016) Kamus Pengantar Ngaju-Indonesia PT Sinar Bagawan Khatulistiwa, Palangka Raya.

Soerojo, Wignjodipoero, (1984) Pengantar Dan Asas-Asas Hukum Adat: PT. Gunung Agung, Jakarta.

Wulansari, C.Dewi (2016). Hukum Adat Indonesia PT Refika Aditama, Bandung.

\section{Jurnal}

Abubakar, Lastuti, 'Revitalisasi Hukum Adat Sebagai Sumber Hukum Dalam Membangun Sistem Hukum Indonesia', Dinamika Hukum, 13 (2) (2013), 320-31 <http://www.dinamikahukum.fh.unsoed.ac.id/index.php/JDH/article/view/2 $13 / 161>$

Arliman, Laurensius, 'Hukum Adat Indonesia Dalam Pandangan Para Ahli Dan Konsep Pemberlakuannya Di Indonesia', Jurnal Selat, 5 (2) (2018), 179-90 <https:// doi.org/https:/ / doi.org/10.31629/selat.v5i2.320>

Harahap, Asliani, 'Pembaharuan Hukum Pidana Berbasis Hukum Adat', Jurnal EduTech, 4 (2) (2018) <https:/ / doi.org/https:/ / doi.org/10.30596/ edutech.v4i2.2268>

Harmaini, and Febrian Chandra, 'Selayang Pandang Hukum Adat Di Kabupaten Merangin (Kajian Masyarakat Hukum Adat)', Adil Jurnal Hukum STIH YPM, 2 (2020), 34 <http://adil.stihypm.ac.id/index.php/ojs/article/view/9/11>

Kastama, I Made, 'Hukum Adat Dayak : Bentuk, Penerapan Dan Sanksi Singer Di Desa Pandreh Kecamatan Teweh Tengah Kabupaten Barito Utara', Belom Bahadat, VIII (2018) <https:// doi.org/https:/ / doi.org/10.33363/bb.v8i2.206>

Pratiwi, Putri Fransiska Purnama, Suprayitno, and Triyani, 'Upaya Hukum Untuk Menjerat Tindakan Pelakor Dalam Perspektif Hukum Adat Dayak Ngaju', Jurnal $\begin{array}{lllll}\text { Cakrawala Hukum, } & 10 & \text { No.2 }\end{array}$ <https://doi.org/https:/ / doi.org/10.26905/>

'Prosesi Pernikahan Adat Dayak Ngaju Di Kalimantan Tengah', Gpswisataindonesia, 2017 <https://gpswisataindonesia.info/2017/01/prosesi-pernikahan-adat-dayakngaju-kalimantan-tengah-ngaju/>

Rampai, Darwis Luther, 'Perkawinan Menurut Hukum Adat Dayak Ngaju Kalimantan Tengah Ditinjau Dari Undang-Undang Nomor 1 Tahun 1974' (Universitas Airlangga, 2003) <http://repository.unair.ac.id/35031/12/jiptunair-gdl-s2-2004rampay2c-1042-perkawinan-th_29-03.pdf >

Susylawati, Eka, 'Eksistensi Hukum Adat Dalam Sistem Hukum Di Indonesia', Jurnal $\begin{array}{lllll}\text { Hukum Dan Pranata Sosial, } 4 & \text { (1) }\end{array}$ <https:// doi.org/https:/ / doi.org/10.19105/al-lhkam.v4i1.267>

Tobing, Gindo L, 'Hukum Adat Sebagai Pranata Umum Penyelesaian Perselisihan Melalui Musyawarah Mufakat Dalam Lingkungan Masyarakat', Jurnal Hukum To$\begin{array}{lll}\mathrm{Ra} \text {, } & 2 & \text { (2016), }\end{array}$ <http:/ / ejournal.uki.ac.id/index.php/tora/article/view/1105/932>

Yunus, Ahyuni, and Ahmad Ali Muddin, 'Penyelesaian Sengketa Tanah Ulayat Yang Telah Bersertifikat Berdasarkan Hukum Adat Malind-Anim', Kertha Patrika, 41(3) (2019), 206-21 <https:/ / doi.org/10.24843/KP.2019.v41.i03.p03> 


\section{Internet}

Hadi, Ilman, 'Kekuatan Hukum Putusan Adat', Hukum Online, 2012 <https://www.hukumonline.com/klinik/detail/ulasan/lt4fbb44750563e/kekuat an-hukum-putusan-adat/>

'Kamus Besar Bahasa Indonesia' < https://jagokata.com/artikata/wewenang.html\#: :text=\%5Bwewenang\%5D Makna wewenang di KBBI,arti dan definisi di jagokata.>

\section{Peraturan Perundang-Undangan}

Undang-Undang Dasar Republik Indonesia 1945

Undang-Undang Nomor 1 Tahun 1974 Tentang Perkawinan

Peraturan Daerah Provinsi Kalimantan Tengah Nomor 16 Tahun 2008 Tentang Kelembagaan Adat Dayak Di Kalimantan Tengah, 2008

Peraturan Menteri Dalam Negeri Nomor 5 Tahun 2007 Tentang Pedoman Penataan Lembaga Kemasyarakatan

Dewan Adat Dayak, Pedoman Peradilan Adat Dayak Kalimantan Tengah, 2015 